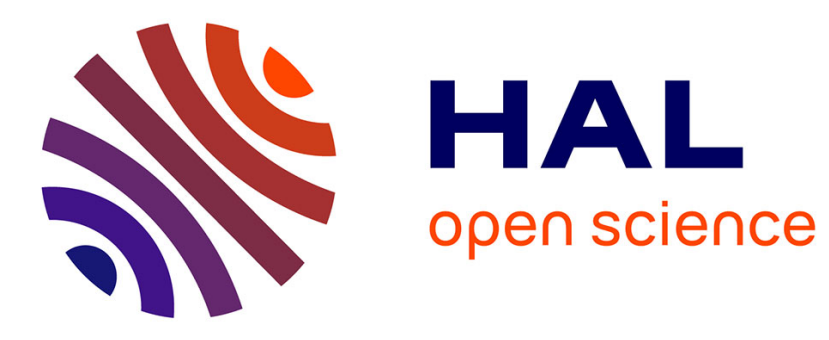

\title{
Practical Synthesis and Application of Halogen-Doped Pyrrole Building Blocks
}

Andrej Emanuel Cotman, Thomas Guérin, Ivana Kovačević, Davide

Benedetto Tiz, Martina Durcik, Federica Fulgheri, Štefan Možina, Daniela

Secci, Maša Sterle, Janez Ilaš, et al.

\section{To cite this version:}

Andrej Emanuel Cotman, Thomas Guérin, Ivana Kovačević, Davide Benedetto Tiz, Martina Durcik, et al.. Practical Synthesis and Application of Halogen-Doped Pyrrole Building Blocks. ACS Omega, 2021, 6 (14), pp.9723-9730. 10.1021/acsomega.1c00331 . hal-03228819

\section{HAL Id: hal-03228819 https://hal.science/hal-03228819}

Submitted on 18 May 2021

HAL is a multi-disciplinary open access archive for the deposit and dissemination of scientific research documents, whether they are published or not. The documents may come from teaching and research institutions in France or abroad, or from public or private research centers.
L'archive ouverte pluridisciplinaire HAL, est destinée au dépôt et à la diffusion de documents scientifiques de niveau recherche, publiés ou non, émanant des établissements d'enseignement et de recherche français ou étrangers, des laboratoires publics ou privés. 


\section{Practical Synthesis and Application of Halogen-Doped Pyrrole Building Blocks}

Andrej Emanuel Cotman, Thomas Guérin, Ivana Kovačević, Davide Benedetto Tiz, Martina Durcik, Federica Fulgheri, Stefan Možina, Daniela Secci, Maša Sterle, Janez Ilaš, Anamarija Zega, Nace Zidar, Lucija Peterlin Mašič, Tihomir Tomašič, Frédéric R. Leroux, Gilles Hanquet, and Danijel Kikelj*

Cite This: https://doi.org/10.1021/acsomega.1c00331

ABSTRACT: A practical access to four new halogen-substituted pyrrole building blocks was realized in two to five synthetic steps from commercially available starting materials. The target compounds were prepared on a $50 \mathrm{mg}$ to $1 \mathrm{~g}$ scale, and their conversion to nanomolar inhibitors of bacterial DNA gyrase B was demonstrated for three of the prepared building blocks to showcase the usefulness of such chemical motifs in medicinal chemistry.

\section{INTRODUCTION}

Halogen-substituted pyrrole-2-carboxamide is an integral molecular fragment of bioactive marine natural products as well as natural and synthetic anti-infectives (Figure 1). In

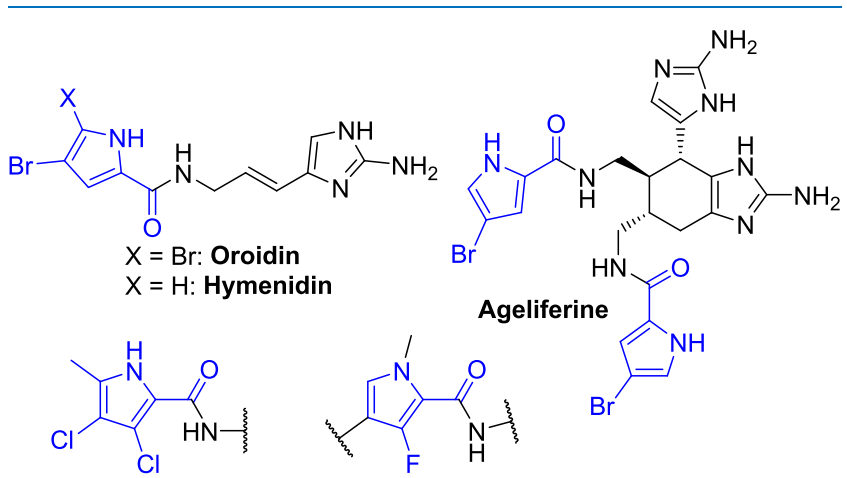

Antibacterial agents Antiviral agents

Figure 1. Representative natural products and bioactive compounds with a halogen-doped $1 H$-pyrrole-2-carboxamide fragment.

particular, mono- and dibromopyrrole-2-carboxamide are found in oroidin ${ }^{1}$ and hymenidin, ${ }^{2}$ which are postulated precursors for structurally diverse mono- and oligomeric secondary metabolites involved in the chemical defense of Agelas marine sponges. A representative compound ageliferin ${ }^{3}$ features a complex multichiral scaffold. ${ }^{4}$ Furthermore, 3,4dichloro-5-methyl- $1 \mathrm{H}$-pyrrole-2-carboxamide is a molecular fragment of natural ${ }^{5,6}$ and synthetic ${ }^{7}$ antibacterials, crucial for binding to the active site of bacterial topoisomerases, and the 3-fluoro- $1 H$-pyrrole-2-carboxamide moiety is found in promising preclinical candidates, active against hepatitis $B$ virus (Figure 1). ${ }^{8}$

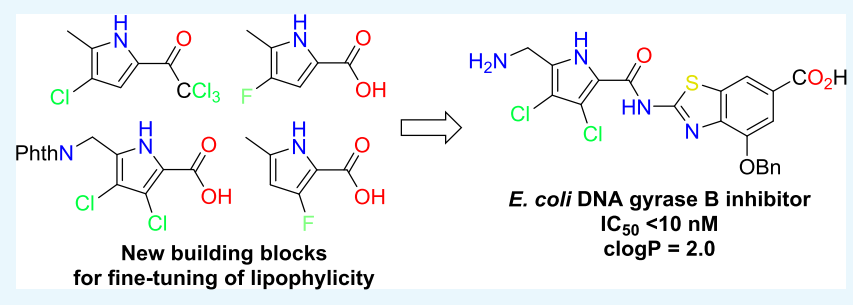

During our ongoing research in the field of dual bacterial DNA gyrase/topoisomerase IV inhibitors, ${ }^{9-15}$ a promising hit compound 1 (Figure 2) was identified, displaying low

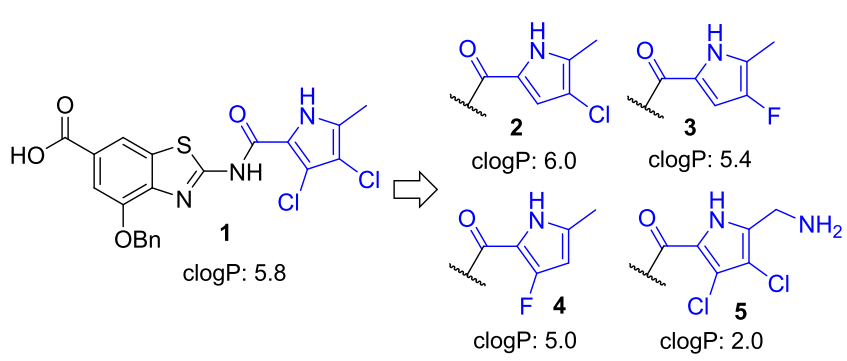

Figure 2. Design of antibacterial hit compound analogues with decreased lipophilicity.

nanomolar inhibition of the target enzymes and broadspectrum activity against gram-positive bacterial strains. ${ }^{16}$ Due to the compound's high lipophilicity, its more polar analogues 2-5 were designed by varying the 3,4-dichloro-5methyl-1H-pyrrole moiety, envisioning improved physical properties $(c \log P$ was calculated by ChemDraw) of the analogues while retaining the on-target activity (Figure 2).

With no preceding literature on the synthesis of the required pyrrole building blocks for the preparation of compounds 2-5, we report herein our synthetic endeavors, where the main goal

Received: January 19, 2021

Accepted: March 18, 2021 
was the timely delivery of at least $100 \mathrm{mg}$ of the sample to be built into the bioactive molecules. The amide bond of the target compounds can be formed using pyrrole-2-carbonyl chloride or 2-trichloroacetylpyrrole; therefore, either would be an acceptable option.

\section{RESULTS AND DISCUSSION}

The literature procedure for the synthesis of 4-chloro-5methyl-1H-pyrrole-2-carboxylic acid involves chlorination of ethyl 5-methyl-1H-pyrrole-2-carboxylate using $\mathrm{N}$-chlorosuccinimide at $0{ }^{\circ} \mathrm{C}$ and required in our hands laborious chromatographic separation of two barely resolved products. ${ }^{17}$ The practical synthesis of an alternative acylating agent 8 for the introduction of the same structural fragment was thus developed (Scheme 1). Trichloroacetylpyrrole 7 was prepared

Scheme 1. Synthesis of 2-Trichloroacetyl-4-chloro-5methyl-1H-pyrrole $8^{a}$

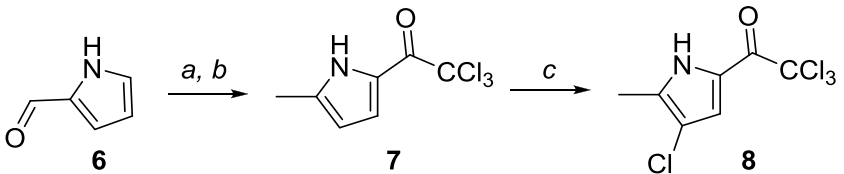

${ }^{a}$ Reagents and conditions: (a) $\mathrm{NH}_{2} \mathrm{NH}_{2} \cdot \mathrm{H}_{2} \mathrm{O}$, ethylene glycol, $90{ }^{\circ} \mathrm{C}$, $1 \mathrm{~h}$, then $\mathrm{KOH}, 90^{\circ} \mathrm{C}, 2.5 \mathrm{~h}$ (70\% yield); (b) $\mathrm{CCl}_{3} \mathrm{COCl}, \mathrm{Et}_{2} \mathrm{O}$, r.t., 2 h $(60 \%$ yield $)$; and (c) $N$-chlorosuccinimide, dichloromethane, r.t., 4 $\mathrm{h}(61 \%$ yield).

from pyrrole-2-carbaldehyde 6 employing the Wolff-Kishner reduction and Friedel-Crafts acylation. ${ }^{18}$ It was then directly monochlorinated using $N$-chlorosuccinimide at r.t. and the pure product 8 was obtained on the gram scale in $61 \%$ isolated yield after convenient crystallization from dichloromethane. Its structure was unambiguously determined by two-dimensional (2D) nuclear magnetic resonance (NMR) experiments (Supporting Information), showing that the electrophilic chlorination was selective for the position next to the electron-donating methyl substituent.

Next, we targeted the 4-fluoro-substituted building block. The screening of different halogen exchange ("Halex") conditions involving crown ether 18-C-6 and [2.2.2] cryptand, for the conversion of chloropyrrole 8 or ethyl 4-chloro-5methylpyrrole-2-carboxylate to the corresponding arylfluorides, returned no hits. ${ }^{19}$ We thus resorted to electrophilic fluorination of ethyl 5-methyl-1H-pyrrole-2-carboxylate 9 (Scheme 2). Initial $0.5 \mathrm{mmol}$ scale screening of the reaction conditions (Table S1 in the Supporting Information) revealed that Selectfluor-mediated fluorination ${ }^{20}$ outperformed the $N$ fluorobenzenesulfonimide (NFSI)-mediated Lewis acid-catalyzed fluorination, ${ }^{21}$ as the former resulted in somewhat cleaner conversions. When the fluorination was performed at 0 ${ }^{\circ} \mathrm{C}$ in a mixture of acetonitrile and acetic acid (Table S2, entries 11 and 12), the formation of target compound 10, accompanied by an acetoxy side product 11, was observed. Their structures were confirmed by single-crystal X-ray diffraction analysis (Figures $\mathrm{S} 1$ and $\mathrm{S} 2$ in the Supporting Information). Aiming for an efficient med-chem synthetic route, the reaction was performed on a $2 \mathrm{~g}$ scale (Scheme 2), delivering 10 in a consistent $4.5-6.5 \%$ yield after flash chromatography. Ester 10 was hydrolyzed to acid 12, requiring rather forcing conditions, and acyl chloride 13 was finally formed using oxalyl chloride in dichloromethane. It is
Scheme 2. Synthesis of 4-Fluoro-5-methyl-1H-pyrrole-2carbonyl Chloride $13^{a}$

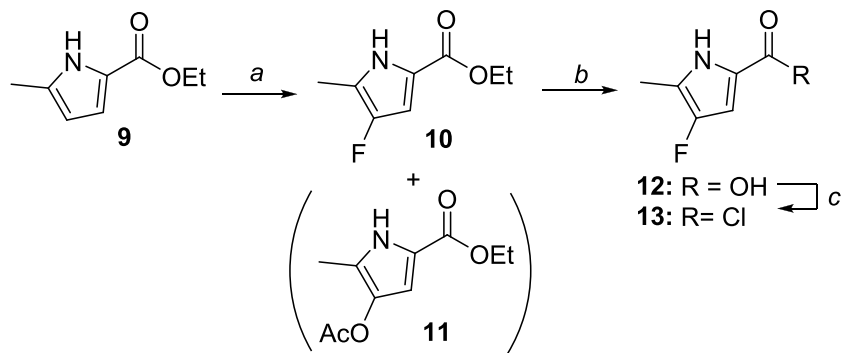

${ }^{a}$ Reagents and conditions: (a) Selectfluor, $\mathrm{MeCN} / \mathrm{AcOH}$ 5:1, $0{ }^{\circ} \mathrm{C}, 2$ h (6.5\% yield); (b) $10 \mathrm{M} \mathrm{NaOH} \mathrm{(aq),} \mathrm{EtOH,} 90{ }^{\circ} \mathrm{C}, 3 \mathrm{~h}$ (76\% yield); and (c) oxalyl chloride, dichloromethane, r.t., overnight (quant. yield).

noteworthy that acyl chloride formation using refluxing sulfonyl chloride or oxalyl chloride with the catalytic quantity of dimethylformamide (DMF) resulted in the formation of a significant amount of unidentified side products.

Ethyl 3-fluoro-1H-pyrrole-2-carboxylate $\mathbf{1 4}$ has recently become commercially available at a reasonable price because it is a key building block for a drug candidate against hepatitis B virus. ${ }^{22}$ This was a good starting point for the synthesis of 3fluoro-5-methyl-1H-pyrrole-2-carboxylic acid 18 (Scheme 3).

Scheme 3. Synthesis of 3-Fluoro-5-methyl-1H-pyrrole-2carbonyl Chloride $19^{a}$

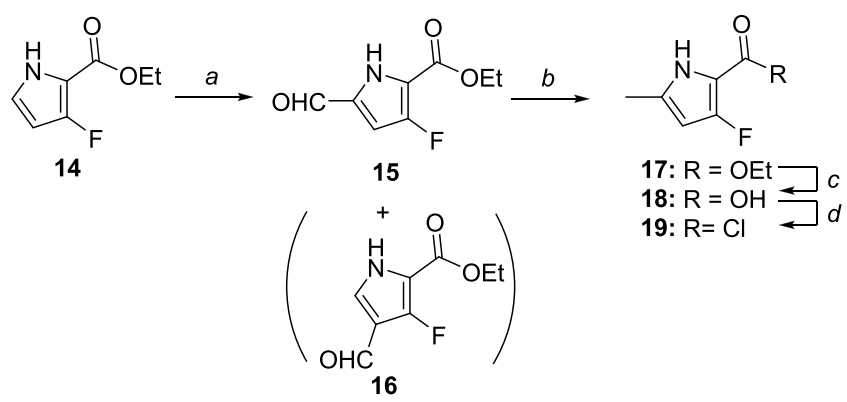

${ }^{a}$ Reagents and conditions: (a) DMF, $\mathrm{POCl}_{3}, 0{ }^{\circ} \mathrm{C}, 30 \mathrm{~min}$, then 14 , $90{ }^{\circ} \mathrm{C}$, overnight ( $25 \%$ yield); (b) $\mathrm{Zn}, 4 \mathrm{M} \mathrm{HCl} /$ dioxane, r.t., $40 \mathrm{~min}$ (20\% yield); (c) $10 \mathrm{M} \mathrm{NaOH}(\mathrm{aq}), \mathrm{EtOH}, 90{ }^{\circ} \mathrm{C}, 5 \mathrm{~h}$ ( $82 \%$ yield); and (d) oxalyl chloride, dichloromethane, r.t., overnight (quant. yield).

The Vilsmeier-Haack formylation of $\mathbf{1 4}$ gave at $68 \%$ conversion a 43:57 mixture of 4- and 5-formylated regioisomers 16 and 15, which were separated by flash chromatography. The regioisomers' identity was assigned by ${ }^{19}$ F NMR as follows: 4-formyl isomer 16 features a singlet and 5-formyl isomer 15 features a doublet, ${ }^{3} J_{\mathrm{F}, \mathrm{H}}=4 \mathrm{~Hz}$, confirming the presence of a vicinal proton. Moreover, the ${ }^{13} \mathrm{C}$ NMR peak of the formyl carbon of $\mathbf{1 5}$ is a singlet and that of $\mathbf{1 6}$ is a doublet, ${ }^{3} J_{\mathrm{C}, \mathrm{F}}=2.8 \mathrm{~Hz}$.

Based on the literature reports on the reduction of estercontaining formylpyrroles to methylpyrroles, ${ }^{23}$ we first attempted a $\mathrm{BH}_{3} \cdot \mathrm{THF}-\mathrm{mediated}$ reduction of 15-17, which in this case yielded the intermediate alcohol; no full reduction was observed even after several days of stirring with periodical addition of excess $\mathrm{BH}_{3} \cdot \mathrm{THF}$. Other literature reports on aldehyde-to-methyl reduction in the presence of ester include a two-step Mozingo protocol via thioketal. ${ }^{24}$ Aiming to secure a 
convenient one-pot procedure, we opted for the modified Clemmensen reduction. ${ }^{25}$ A dioxane-soluble $\left.\left[\mathrm{ZnCl}_{2} \text { (dioxane }\right)_{2}\right]$ complex $^{26}$ was prepared by treating zinc dust with anhydrous $4 \mathrm{M} \mathrm{HCl}$ in dioxane. This proved to be a very efficient and reasonably selective reduction medium, delivering 17 after $40 \mathrm{~min}$ at r.t. in $20 \%$ isolated yield. Optimization of the reaction conditions and elucidation of the mechanism is beyond the aim of this study; however, we speculate that a dioxane-soluble $\mathrm{Zn}$ (II) species forms a zincylide intermediate more efficiently compared to the classical heterogeneous Clemmensen reduction $\left(\mathrm{Zn} / \mathrm{Hg} / \mathrm{HCl} / \mathrm{H}_{2} \mathrm{O}\right)$, allowing the reaction to proceed at room temperature. ${ }^{27}$ The side products are essentially a result of the zinc-ylide reaction with other present electrophiles (ester, aldehyde, and arylfluoride). Using the conditions developed for the synthesis of 13, ester 17 was readily transformed to acyl chloride 19 .

Ethyl 5-chloromethyl-3,4-dichloro-1 $\mathrm{H}$-pyrrole-2-carboxylate 21 was prepared from commercially available $\mathbf{2 0}$ according to the literature procedure (Scheme 4$).{ }^{18}$ After conversion to

Scheme 4. Synthesis of 3,4-Dichloro-5-phthalimidomethyl1H-pyrrole-2-carboxylic Acid 25 ${ }^{a}$<smiles>[R2]Cc1[nH]c(C(=O)OCC)c(Cl)c1Cl</smiles>
22: $\mathrm{R}=\mathrm{N}_{3} \square \mathrm{R}=\mathrm{NH}_{2} \longleftarrow \mathrm{c}$<smiles>[Z4]c1c(C(=O)O)[nH]c(CN)c1Cl</smiles><smiles>O=C(O)c1[nH]c(CN2C(=O)c3ccccc3C2=O)c(Cl)c1Cl</smiles>

${ }^{a}$ Reagents and conditions: (a) $\mathrm{SO}_{2} \mathrm{Cl}_{2}, \mathrm{CCl}_{4},-5{ }^{\circ} \mathrm{C}, 5 \mathrm{~h}$; (b) $\mathrm{NaN}_{3}$, $\mathrm{KI}$ (cat.), DMF, r.t., $1.5 \mathrm{~h}$ (95\% yield); (c) $\mathrm{PPh}_{3}, \mathrm{H}_{2} \mathrm{O} / \mathrm{THF}$, r.t., $2.5 \mathrm{~h}$ (78\% yield); (d) $10 \mathrm{M} \mathrm{NaOH}, \mathrm{EtOH}, 90{ }^{\circ} \mathrm{C}, 4 \mathrm{~h}$ (quant. yield); and (e) phthalic anhydride, $130-180{ }^{\circ} \mathrm{C}, 1 \mathrm{~h}$ (55\% yield).

azide 22 by KI-mediated nucleophilic substitution, the reduction of 22 to amine 23 was first attempted via $\mathrm{Pd} / \mathrm{C}$ catalyzed hydrogenation. This resulted in significant sideproduct formation, possibly via the nucleophilic attack of amine $\mathbf{2 3}$ to the electrophilic methylene moiety of $\mathbf{2 2}$, and aryl dehalogenation, as apparent from the ${ }^{1} \mathrm{H}$ NMR analysis of the crude reaction mixture. Avoiding the coexistence of amine and azide species during the reaction, we resorted to the milder Staudinger reduction, ${ }^{28}$ which furnished amine 23 in $78 \%$ isolated yield. Saponification to $\mathbf{2 4}$, followed by phthalimide protection in neat phthalic anhydride gave 25 with $41 \%$ yield over four steps from 21.

To showcase the usefulness of the prepared building blocks in medicinal chemistry, the synthesis of compound 5 , the analogue of antibacterial hit compound 1, was tackled (Scheme 5). After the smooth coupling of the acyl chloride, prepared from $\mathbf{2 5}$ in neat thionyl chloride, with the 2 -aminobenzothiazole building block $^{29}$ in refluxing toluene, the deprotection step required some special attention. The formation of stable hydrazinium salt $\mathbf{2 7}$ was observed during the phthalimide deprotection, arguably due to the electronwithdrawing character of dichloropyrrole, which increases the acidity of the neighboring amides. It was crucial to first reprotonate the nitrogens of 27 to achieve complete
Scheme 5. Synthesis of DNA Gyrase B Inhibitor $5 \cdot \mathrm{HCl}^{a}$<smiles>COC(=O)c1cc(OCc2ccccc2)c2nc(NC(=O)c3[nH]c(CNPc4ccccc4)c(Cl)c3Cl)sc2c1</smiles>

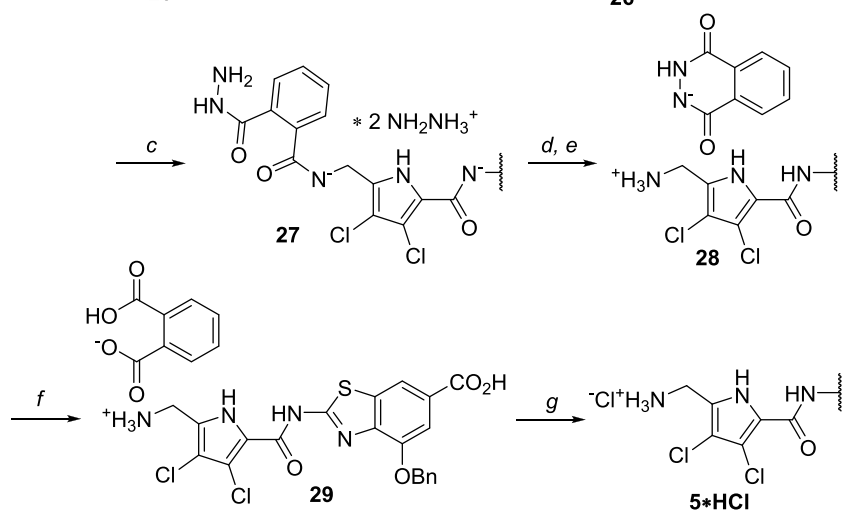

${ }^{a}$ Reagents and conditions: (a) $\mathrm{SOCl}_{2}, 75{ }^{\circ} \mathrm{C}, 1 \mathrm{~h}$ (quant. yield); (b) methyl 2-amino-4-benzyloxybenzo[d] thiazole-6-carboxylate, toluene, $130{ }^{\circ} \mathrm{C}, 24 \mathrm{~h}$ ( $81 \%$ yield); (c) $\mathrm{NH}_{2} \mathrm{NH}_{2} \cdot \mathrm{H}_{2} \mathrm{O}, \mathrm{EtOH}, 50{ }^{\circ} \mathrm{C}, 40 \mathrm{~min}$; (d) $\mathrm{HCl}, \mathrm{MeOH}$, r.t., 15 min; (e) $\mathrm{EtOH}, 80^{\circ} \mathrm{C}, 18 \mathrm{~h}$ (88\% yield from 26); (f) $4 \mathrm{M} \mathrm{KOH}, \mathrm{EtOH}, 50^{\circ} \mathrm{C}, 24 \mathrm{~h}$ then $1 \mathrm{M} \mathrm{HCl}$ to $\mathrm{pH}=9$; and (g) $\mathrm{HCl}, \mathrm{MeOH}$, r.t. ( $55 \%$ yield from 28 ).

deprotection after refluxing in ethanol overnight. Alkaline hydrolysis of phthalic hydrazide salt $\mathbf{2 8}$ yielded phthalate salt 29 and the anion was readily exchanged to the chloride salt of 5 by trituration with methanolic $\mathrm{HCl}$.

Antibacterial hit compound $1(c \log P=5.8)$ inhibited Escherichia coli DNA gyrase with $\mathrm{IC}_{50}<10 \mathrm{nM}$, and compound $5(c \log P=2.0)$ inhibited the same enzyme with $\mathrm{IC}_{50}<10$ nM. Moreover, 5 exhibits activity against Staphylococcus aureus (ATCC29213) with a minimal inhibitory concentration of 1 $\mu \mathrm{g} / \mathrm{mL}$. This confirms the hypothesis that the single-digit nanomolar inhibitory on-target activity coupled to the antibacterial activity can be retained while significantly reducing the lipophilicity by the modification of the pyrrole moiety.

To explore the reactivity and bioactivity of the fluorinated pyrroles, two additional analogues of $\mathbf{1}$ were prepared (Scheme 6 ) and evaluated for their on-target and antibacterial activities. Thus, compounds 31 and 33 inhibited E. coli DNA gyrase with $\mathrm{IC}_{50}$ values of 32 and $150 \mathrm{nM}$, respectively, and possessed weak activity against $S$. aureus (ATCC29213) (31: MIC $=64$ $\mu \mathrm{g} / \mathrm{mL} ; 33: \mathrm{MIC}>64 \mu \mathrm{g} / \mathrm{mL})$.

\section{CONCLUSIONS}

In summary, practical synthetic routes to four new halogendoped pyrrole building blocks were developed, delivering the target compounds in sufficient quantities for further elaboration. Moreover, the transformation of the building blocks to potent DNA gyrase B inhibitors was demonstrated. Such building blocks are polar alternatives to molecular fragments found in naturally occurring or natural-product-inspired bioactive compounds and are useful in hit-to-lead optimization.

\section{EXPERIMENTAL SECTION}

4.1. General. Reactions were conducted under an inert atmosphere using anhydrous solvents when required. Analytical thin-layer chromatography (TLC) was performed on silica gel $60 \mathrm{~F}_{254}$ plates. Flash column chromatography was 
Scheme 6. Synthesis of DNA Gyrase B Inhibitors 31 and $33^{a}$

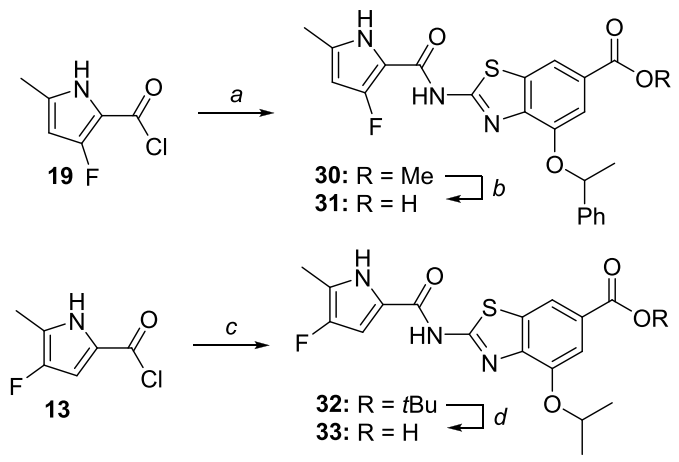

${ }^{a}$ Reagents and conditions: (a) methyl 2-amino-4-(1-phenylethoxy)benzo[d]thiazole-6-carboxylate, toluene, $130{ }^{\circ} \mathrm{C}, 24 \mathrm{~h}$ (57\% yield); (b) $\mathrm{MeOH}, 2 \mathrm{M} \mathrm{NaOH}, 40{ }^{\circ} \mathrm{C}, 48 \mathrm{~h}$; (c) tert-butyl 2-amino-4-(2propyloxy)benzo[d] thiazole-6-carboxylate, toluene, $130{ }^{\circ} \mathrm{C}, 24 \mathrm{~h}$ (79\% yield); and (d) $\mathrm{CF}_{3} \mathrm{COOH}, \mathrm{DCM}$, r.t., $24 \mathrm{~h}$ (98\% yield).

performed using silica gel $60(40-63 \mu \mathrm{m})$. Melting points were determined on a Kofler apparatus and are uncorrected. ${ }^{1} \mathrm{H}$ NMR (400 MHz, internal $\left.\mathrm{Me}_{4} \mathrm{Si}\right),{ }^{13} \mathrm{C}$ NMR $(101 \mathrm{MHz}$, internal $\mathrm{CDCl}_{3}$ or DMSO- $d_{6}$ ), and ${ }^{19} \mathrm{~F}$ NMR $(376 \mathrm{MHz}$, external $\mathrm{CCl}_{3} \mathrm{~F}$ ) spectra were recorded on a Bruker AVANCE III 400 spectrometer (Bruker Corporation, Billerica, MA) in a DMSO- $d_{6}$ or $\mathrm{CDCl}_{3}$ solution. HRMS analysis was performed on a VG Analytical Autospec Q mass spectrometer (Fisons, VG Analytical, Manchester, U.K.).

4.2. Synthetic Procedures. 4.2.1. 2-Trichloroacetyl-4chloro-5-methyl-1H-pyrrole (8). A mixture of 2-trichloroacetyl-5-methyl-1H-pyrrole $(2.14 \mathrm{~g}, 9.44 \mathrm{mmol}), \mathrm{N}$-chlorosuccinimide $(1.26 \mathrm{~g}, 9.44 \mathrm{mmol})$, and dichloromethane $(9.0 \mathrm{~mL})$ was stirred at r.t. overnight. The reaction mixture was partitioned between EtOAc $(50 \mathrm{~mL})$ and water $(50 \mathrm{~mL})$, and the organic layer was washed with water and brine, dried $\left(\mathrm{Na}_{2} \mathrm{SO}_{4}\right)$, and concentrated. The residue was recrystallized from dichloromethane to get the title compound as white crystals $(1.51 \mathrm{~g}, 61 \%$ yield $)$. Mp $140-142{ }^{\circ} \mathrm{C}(\mathrm{DCM}) .{ }^{1} \mathrm{H}$ $\operatorname{NMR}\left(400 \mathrm{MHz}, \mathrm{CDCl}_{3}\right) \delta 10.37(\mathrm{~s}, 1 \mathrm{H}), 7.31(\mathrm{~d}, J=2.9 \mathrm{~Hz}$, $1 \mathrm{H}), 2.41(\mathrm{~s}, 2 \mathrm{H}) .{ }^{13} \mathrm{C}$ NMR $\left(101 \mathrm{MHz}, \mathrm{CDCl}_{3}\right) \delta 172.89$, $137.01,121.03,119.78,114.13,94.87,11.37$. HRMS calcd for $\mathrm{C}_{7} \mathrm{H}_{4} \mathrm{ONCl}_{4}[\mathrm{M}-\mathrm{H}]^{-}$257.90525, found 257.90521 .

4.2.2. Ethyl 4-Fluoro-5-methyl-1H-pyrrole-2-carboxylate (10). To a solution of ethyl 5-methyl- $1 \mathrm{H}$-pyrrole-2-carboxylate $(2.00 \mathrm{~g}, 13.1 \mathrm{mmol})$ in acetonitrile $(360 \mathrm{~mL})$ and $\mathrm{AcOH}(72$ $\mathrm{mL}$ ) at $0{ }^{\circ} \mathrm{C}$ was added Selectfluor $(9.25 \mathrm{~g}, 26.1 \mathrm{mmol})$, and the mixture was stirred at $0{ }^{\circ} \mathrm{C}$ for $2 \mathrm{~h}$ (full conversion by ${ }^{1} \mathrm{H}$ NMR). The reaction mixture was partitioned between water $(500 \mathrm{~mL})$ and dichloromethane $(500 \mathrm{~mL})$, and the organic layer was washed with sat. $\mathrm{NaHCO}_{3}$ (aq) and brine, dried $\left(\mathrm{Na}_{2} \mathrm{SO}_{4}\right)$, and concentrated to get the crude product. Crude products from two $2 \mathrm{~g}$ runs were combined and purified by flash chromatography, eluent hexane/EtOAc $4: 1$, to get the title compound (first eluting) as a colorless amorphous solid $\left(288 \mathrm{mg}, 6.5 \%\right.$ yield). ${ }^{1} \mathrm{H}$ NMR $\left(400 \mathrm{MHz}, \mathrm{CDCl}_{3}\right): \delta 8.92$ (bs, $1 \mathrm{H}), 6.54(\mathrm{~d}, 1 \mathrm{H}, J=4.0 \mathrm{~Hz}), 4.30(\mathrm{q}, 2 \mathrm{H}, J=7.1 \mathrm{~Hz})$, $2.24(\mathrm{~s}, 3 \mathrm{H}), 1.34(\mathrm{t}, 3 \mathrm{H}, J=7.1 \mathrm{~Hz}) \cdot{ }^{13} \mathrm{C}$ NMR $(101 \mathrm{MHz}$, $\left.\mathrm{CDCl}_{3}\right) \delta 161.3(\mathrm{~d}, J=3.3 \mathrm{~Hz}), 148.9(\mathrm{~d}, J=238.7 \mathrm{~Hz}), 117.6$, $116.2(\mathrm{~d}, J=7.4 \mathrm{~Hz}), 102.3(\mathrm{~d}, J=15.6 \mathrm{~Hz}), 60.6,14.6,9.4(\mathrm{~d}$, $J=2.1 \mathrm{~Hz}) .{ }^{19} \mathrm{~F}$ NMR $\left(376 \mathrm{MHz}, \mathrm{CDCl}_{3}\right): \delta-166.4$. HRMS calcd for $\mathrm{C}_{8} \mathrm{H}_{11} \mathrm{FNO}_{2}[\mathrm{M}+\mathrm{H}]^{+}$172.0768, found 172.0769.
This procedure was repeated several times, consistently yielding $4.5-6.5 \%$ of the title compound. A monocrystal suitable for single-crystal $\mathrm{X}$-ray diffraction analysis was grown from dichloromethane/hexane.

4.2.3. Ethyl 4-Acetoxy-5-methyl-1H-pyrrole-2-carboxylate (11). Ethyl 4-acetoxy-5-methyl-1H-pyrrole-2-carboxylate was isolated as a second eluting product (see purification of $\mathbf{1 0}$ above), a white amorphous solid. ${ }^{1} \mathrm{H}$ NMR (400 MHz, $\left.\mathrm{CDCl}_{3}\right): \delta 10.10(\mathrm{~s}, 1 \mathrm{H}), 6.72(\mathrm{~d}, J=2.8 \mathrm{~Hz}, 1 \mathrm{H}), 4.29(\mathrm{q}, J=$ $7.1 \mathrm{~Hz}, 1 \mathrm{H}), 2.24(\mathrm{~s}, 1 \mathrm{H}), 2.16(\mathrm{~s}, 1 \mathrm{H}), 1.32(\mathrm{t}, J=7.1 \mathrm{~Hz}$, $1 \mathrm{H}) .{ }^{13} \mathrm{C}$ NMR $\left(101 \mathrm{MHz}, \mathrm{CDCl}_{3}\right): \delta 169.23,161.46,134.49$, $123.33,117.80,108.22,60.46,20.85,14.55,10.16$. A monocrystal suitable for single-crystal X-ray diffraction analysis was grown from dichloromethane/hexane.

4.2.4. 4-Fluoro-5-methyl-1H-pyrrole-2-carboxylic Acid (12). A solution of the above ester $10(280 \mathrm{mg}, 1.07 \mathrm{mmol})$ in abs. $\mathrm{EtOH}(15 \mathrm{~mL})$ and $10 \mathrm{M} \mathrm{NaOH}(3.0 \mathrm{~mL})$ was stirred at $90{ }^{\circ} \mathrm{C}$ under an argon atmosphere for $3 \mathrm{~h}$, and then the reaction mixture was concentrated under reduced pressure. The residue was acidified to $\mathrm{pH}=3$ by adding $4 \mathrm{M} \mathrm{HCl}$, and the precipitate was collected, washed with water, and air-dried to get the title compound as a light brown amorphous solid (177 mg, 76\% yield). ${ }^{1} \mathrm{H}$ NMR ( $400 \mathrm{MHz}$, DMSO- $d_{6}$ ) $\delta 12.25$ $(\mathrm{s}, 1 \mathrm{H}), 11.51(\mathrm{~s}, 1 \mathrm{H}), 6.45(\mathrm{dd}, J=2.9,1.1 \mathrm{~Hz}, 1 \mathrm{H}), 2.13(\mathrm{~s}$, 3H). ${ }^{19} \mathrm{~F}$ NMR (376 MHz, DMSO-d 6 ) $\delta-167.66$ to -167.70 (m). ${ }^{13} \mathrm{C}$ NMR $\left(101 \mathrm{MHz}\right.$, DMSO-d $\left.d_{6}\right) \delta 161.51(\mathrm{~d}, J=3.3$ $\mathrm{Hz}), 147.77(\mathrm{~d}, J=235.0 \mathrm{~Hz}), 116.90(\mathrm{~d}, J=25.1 \mathrm{~Hz}), 116.15$ $(\mathrm{d}, J=7.3 \mathrm{~Hz}), 100.94(\mathrm{~d}, J=14.9 \mathrm{~Hz}), 8.70(\mathrm{~d}, J=2.2 \mathrm{~Hz})$. HRMS calcd for $\mathrm{C}_{6} \mathrm{H}_{5} \mathrm{O}_{2} \mathrm{NF}[\mathrm{M}-\mathrm{H}]^{-} 142.03098$, found 142.03001 .

4.2.5. 4-Fluoro-5-methyl-1H-pyrrole-2-carbonyl Chloride (13). A suspension of the above acid $(75 \mathrm{mg}, 0.52 \mathrm{mmol})$ in dry dichloromethane $(5.2 \mathrm{~mL})$ and oxalyl chloride $(0.45 \mathrm{~mL}$, $5.2 \mathrm{mmol}$ ) was stirred at r.t. overnight. The resulting clear solution was concentrated under reduced pressure to get the title compound as a light brown amorphous solid (quant. yield). ${ }^{1} \mathrm{H}$ NMR $\left(400 \mathrm{MHz}, \mathrm{CDCl}_{3}\right) \delta 8.66(\mathrm{~s}, 1 \mathrm{H}), 6.83(\mathrm{~d}, J$ $=2.8 \mathrm{~Hz}, 1 \mathrm{H}), 2.30(\mathrm{~s}, 3 \mathrm{H}) \cdot{ }^{19} \mathrm{~F}$ NMR shows no clearly identifiable peak.

4.2.6. Ethyl 3-Fluoro-5-formyl-1H-pyrrole-2-carboxylate (15) and Ethyl 3-Fluoro-4-formyl-1H-pyrrole-2-carboxylate (16). To DMF ( $8.9 \mathrm{~mL}, 115 \mathrm{mmol})$ at $0{ }^{\circ} \mathrm{C}$ under Ar was added $\mathrm{POCl}_{3}(1.95 \mathrm{~mL}, 21.0 \mathrm{mmol})$. After stirring at $0{ }^{\circ} \mathrm{C}$ for $30 \mathrm{~min}$, a solution of ethyl 3-fluoro- $1 \mathrm{H}$-pyrrole-2-carboxylate $14(3.00 \mathrm{~g}, 19.1 \mathrm{mmol})$ in DMF $(29 \mathrm{~mL})$ was added, and the resulting solution was stirred at $90{ }^{\circ} \mathrm{C}$ overnight. The reaction mixture was cooled to r.t. and poured onto ice $(100 \mathrm{~mL})$, the $\mathrm{pH}$ was adjusted to 9 by adding $2 \mathrm{M} \mathrm{NaOH}$ (aq) and the product was extracted to $\mathrm{Et}_{2} \mathrm{O}(3 \times 200 \mathrm{~mL})$. The combined organic layers were washed with brine, dried $\left(\mathrm{Na}_{2} \mathrm{SO}_{4}\right)$, and concentrated to get the crude product, containing 14, 5formylated (15), and 4-formylated product (16) in a 42:34:24 ratio (by ${ }^{1} \mathrm{H}$ NMR). The three compounds were separated by column chromatography, eluent dichloromethane, then hexane/EtOAc 2:1 to yield $\mathbf{1 4}$ (983 mg, a white amorphous solid), 15 (869 $\mathrm{mg}, 25 \%$ yield, an orange amorphous solid), and $\mathbf{1 6}$ (724 mg, a yellow amorphous solid).

Compound 15: ${ }^{1} \mathrm{H}$ NMR (400 $\left.\mathrm{MHz}, \mathrm{CDCl}_{3}\right) \delta 9.88$ (s, $1 \mathrm{H}), 9.42(\mathrm{br} \mathrm{s}, 1 \mathrm{H}), 7.36($ app t, $J=3.9 \mathrm{~Hz}, 1 \mathrm{H}), 4.39(\mathrm{q}, J=$ $7.1 \mathrm{~Hz}, 2 \mathrm{H}), 1.39(\mathrm{t}, J=7.1 \mathrm{~Hz}, 3 \mathrm{H}) .{ }^{19} \mathrm{~F}$ NMR $(376 \mathrm{MHz}$, $\left.\mathrm{CDCl}_{3}\right) \delta-150.04(\mathrm{~d}, J=4 \mathrm{~Hz}) \cdot{ }^{13} \mathrm{C}$ NMR $(101 \mathrm{MHz}$, $\left.\mathrm{CDCl}_{3}\right) \delta 183.57,160.22(\mathrm{~d}, J=3.5 \mathrm{~Hz}), 152.93(\mathrm{~d}, J=269.6$ $\mathrm{Hz}), 124.59$ (d, $J=3.6 \mathrm{~Hz}), 115.00(\mathrm{~d}, J=8.5 \mathrm{~Hz}), 109.40$ (d, 
$J=18.1 \mathrm{~Hz}), 61.48,14.35$. HRMS calcd for $\mathrm{C}_{8} \mathrm{H}_{9} \mathrm{O}_{3} \mathrm{NF}[\mathrm{M}+$ $\mathrm{H}]^{+}$186.05610, found 186.05611 .

Compound 16: ${ }^{1} \mathrm{H}$ NMR (400 $\left.\mathrm{MHz}, \mathrm{CDCl}_{3}\right) \delta 9.59(\mathrm{~s}$, $1 \mathrm{H}), 9.47(\mathrm{~s}, 1 \mathrm{H}), 6.71-6.54(\mathrm{~m}, 1 \mathrm{H}), 4.41(\mathrm{q}, J=7.1 \mathrm{~Hz}$, $2 \mathrm{H}), 1.40(\mathrm{t}, J=7.1 \mathrm{~Hz}, 3 \mathrm{H}) .{ }^{19} \mathrm{~F}$ NMR $\left(376 \mathrm{MHz}, \mathrm{CDCl}_{3}\right) \delta$ -146.95. ${ }^{13} \mathrm{C}$ NMR $\left(101 \mathrm{MHz}, \mathrm{CDCl}_{3}\right) \delta 180.38(\mathrm{~d}, J=2.8$ $\mathrm{Hz}), 159.67$ (d, $J=3.9 \mathrm{~Hz}), 153.06(\mathrm{~d}, J=260.3 \mathrm{~Hz}), 129.65$ $(\mathrm{d}, J=4.4 \mathrm{~Hz}), 113.90(\mathrm{~d}, J=20.0 \mathrm{~Hz}), 105.40$ (d, $J=14.2$ $\mathrm{Hz}), 61.75,14.32$.

4.2.7. Ethyl 3-Fluoro-5-methyl-1H-pyrrole-2-carboxylate (17). To a solution of the above aldehyde $15(500 \mathrm{mg}, 2.70$ $\mathrm{mmol})$ in $4 \mathrm{M} \mathrm{HCl}$ in dioxane $(27 \mathrm{~mL})$ was added $\mathrm{Zn}$ dust $(1.78 \mathrm{~g}, 27.0 \mathrm{mmol})$ portionwise at room temperature over 2 min. The reaction is slightly exothermic and performs better if no external cooling is applied. After $40 \mathrm{~min}$ (full conversion by TLC), the reaction mixture was concentrated under reduced pressure and filtered through a plug of silica, eluting with EtOAc $(200 \mathrm{~mL})$, and concentrated to $5 \mathrm{~mL}$, and the colorless crystals were filtered off and washed with EtOAc $\left({ }^{1} \mathrm{H}\right.$ NMR analysis revealed only a dioxane peak; it is likely a dioxanesoluble $\left[\mathrm{ZnCl}_{x}(\text { dioxane })_{x}\right]$ complex involved in the aldehyde reduction). The filtrate was diluted with EtOAc $(200 \mathrm{~mL})$, washed with water $(2 \times 100 \mathrm{~mL}), \mathrm{NaHCO}_{3}(100 \mathrm{~mL})$, and brine, dried $\left(\mathrm{Na}_{2} \mathrm{SO}_{4}\right)$, and concentrated to get the crude product $(486 \mathrm{mg})$, containing $30 \mathrm{~mol} \%$ of the desired product (by ${ }^{19} \mathrm{~F}$ NMR). The pure $\mathbf{1 7}$ was isolated by flash chromatography on silica, eluent hexane/EtOAc 4:1 (first eluting compound) as a colorless oil containing residual EtOAc (by ${ }^{1} \mathrm{H}$ NMR) (94 mg, 20\% yield) and was used as such in the next step. ${ }^{1} \mathrm{H}$ NMR (400 MHz, $\mathrm{CDCl}_{3}$ ) $\delta 8.32$ (br s, $\left.1 \mathrm{H}\right), 6.58$ $-6.51(\mathrm{~m}, 1 \mathrm{H}), 4.33(\mathrm{q}, J=7.1 \mathrm{~Hz}, 2 \mathrm{H}), 2.02(\mathrm{~s}, 3 \mathrm{H}), 1.36(\mathrm{t}$, $J=7.1 \mathrm{~Hz}, 3 \mathrm{H}) .{ }^{19} \mathrm{~F}$ NMR $\left(376 \mathrm{MHz}, \mathrm{CDCl}_{3}\right) \delta-154.53(\mathrm{~d}, J$ $=4.7 \mathrm{~Hz}$ ). HRMS calcd for $\mathrm{C}_{8} \mathrm{H}_{11} \mathrm{O}_{2} \mathrm{NF}[\mathrm{M}+\mathrm{H}]^{+}$172.07683, found 172.07625 .

4.2.8. 3-Fluoro-5-methyl-1H-pyrrole-2-carboxylic Acid (18). A solution of the above ester $17(80 \mathrm{mg}, 0.47 \mathrm{mmol})$ in abs. EtOH $(3.5 \mathrm{~mL})$ and $10 \mathrm{M} \mathrm{NaOH}(0.63 \mathrm{~mL})$ was heated at $90{ }^{\circ} \mathrm{C}$ under $\mathrm{Ar}$ for $2 \mathrm{~h}$, and then it was concentrated under reduced pressure. The oily residue was dissolved in water $(2 \mathrm{~mL})$, and $4 \mathrm{M} \mathrm{HCl}(1.6 \mathrm{~mL})$ was added. The obtained precipitate was collected, washed with water, and airdried to get the title compound as a white amorphous powder (55 mg, 82\% yield). ${ }^{1} \mathrm{H}$ NMR (400 MHz, DMSO- $d_{6}$ ) $\delta 12.32$ $(\mathrm{s}, 1 \mathrm{H}), 11.25(\mathrm{~s}, 1 \mathrm{H}), 6.66($ app t, $J=4.4 \mathrm{~Hz}, 1 \mathrm{H}), 1.93$ (s, 3H). ${ }^{19} \mathrm{~F}$ NMR (376 MHz, DMSO-d $\left.d_{6}\right) \delta-156.45 .{ }^{13} \mathrm{C}$ NMR $\left(101 \mathrm{MHz}, \mathrm{DMSO}-d_{6}\right) \delta 160.49(\mathrm{~d}, J=3.5 \mathrm{~Hz}), 152.39(\mathrm{~d}, J=$ $252.4 \mathrm{~Hz}$ ), $119.46(\mathrm{~d}, J=6.4 \mathrm{~Hz}), 106.77(\mathrm{~d}, J=18.3 \mathrm{~Hz})$, $105.46(\mathrm{~d}, J=13.9 \mathrm{~Hz})$, 7.26. HRMS calcd. for $\mathrm{C}_{6} \mathrm{H}_{7} \mathrm{O}_{2} \mathrm{NF}[\mathrm{M}$ $+\mathrm{H}]^{+}$144.04553, found 144.04552 .

4.2.9. 3-Fluoro-5-methyl-1H-pyrrole-2-carbonyl Chloride (19). A suspension of the above acid $18(50 \mathrm{mg}, 0.35 \mathrm{mmol})$ in dry dichloromethane $(3.5 \mathrm{~mL})$ and oxalyl chloride $(0.3 \mathrm{~mL}$, $3.5 \mathrm{mmol}$ ) was stirred at r.t. overnight. The resulting clear solution was concentrated under reduced pressure to get the title compound as a light brown amorphous solid (quant. yield). ${ }^{1} \mathrm{H}$ NMR (400 MHz, $\left.\mathrm{CDCl}_{3}\right) \delta 8.51$ (br s, $1 \mathrm{H}$ ), 6.81$6.76(\mathrm{~m}, 1 \mathrm{H}), 2.04(\mathrm{~d}, J=0.9 \mathrm{~Hz}, 3 \mathrm{H}) .{ }^{19} \mathrm{~F}$ NMR showed no clearly identifiable peak.

4.2.10. Ethyl 5-(azidomethyl)-3,4-dichloro-1H-pyrrole-2carboxylate (22). To a solution of ethyl 5-(chloromethyl)-3,4dichloro-1H-pyrrole-2-carboxylate $21(2.00 \mathrm{~g}, 7.80 \mathrm{mmol})$ in DMF $(16 \mathrm{~mL})$ was added $\mathrm{NaN}_{3}(1.00 \mathrm{~g}, 15.6 \mathrm{mmol})$, followed by $\mathrm{KI}(130 \mathrm{mg}, 0.78 \mathrm{mmol})$. The resulting suspension was vigorously stirred at r.t. for $1.5 \mathrm{~h}$, and then it was poured into water $(100 \mathrm{~mL})$. The white precipitate was collected, washed with water, and air-dried to yield the title compound as a white amorphous powder (1.95 g, 95\% yield). ${ }^{1} \mathrm{H}$ NMR (400 MHz, $\left.\mathrm{CDCl}_{3}\right) \delta 9.57(\mathrm{~s}, 1 \mathrm{H}), 4.45(\mathrm{~s}, 2 \mathrm{H}), 4.40(\mathrm{q}, J=7.1 \mathrm{~Hz}, 2 \mathrm{H})$, $1.41(\mathrm{t}, J=7.1 \mathrm{~Hz}, 3 \mathrm{H}) .{ }^{13} \mathrm{C}$ NMR $\left(101 \mathrm{MHz} \mathrm{CDCl}_{3}\right) \delta$ $160.08,126.48,118.30,117.72,113.26,61.66,45.22,14.45$. HRMS calcd for $\mathrm{C}_{8} \mathrm{H}_{7} \mathrm{O}_{2} \mathrm{~N}_{4} \mathrm{Cl}_{2}[\mathrm{M}-\mathrm{H}]^{-}$260.99515, found 260.99529.

4.2.11. Ethyl 5-(aminomethyl)-3,4-dichloro-1H-pyrrole-2carboxylate (23). To a solution of the above azide $22(1.70 \mathrm{~g}$, $6.46 \mathrm{mmol})$ in $\mathrm{THF} / \mathrm{H}_{2} \mathrm{O} 10: 1(35 \mathrm{~mL})$ was added $\mathrm{PPh}_{3}(3.39$ g, $12.9 \mathrm{mmol}$ ) at r.t. The resulting amber solution was stirred at r.t. (caution: gas evolution) for $2.5 \mathrm{~h}$, and then it was concentrated under reduced pressure. The oily residue was partitioned between EtOAc $(200 \mathrm{~mL})$ and $0.5 \mathrm{M} \mathrm{HCl}(300$ $\mathrm{mL}$ ). The water layer was brought to $\mathrm{pH}=11$ by adding $2 \mathrm{M}$ $\mathrm{NaOH}$. The precipitate was collected, washed with water, and dried in vacuo to yield the title compound as a white amorphous powder (1.20 g, 78\%). ${ }^{1} \mathrm{H}$ NMR (400 MHz, $\left.\mathrm{CDCl}_{3}\right) \delta 9.87(\mathrm{~s}, 1 \mathrm{H}), 4.36(\mathrm{q}, J=7.1 \mathrm{~Hz}, 2 \mathrm{H}), 3.99(\mathrm{~s}, 2 \mathrm{H})$, $1.63(\mathrm{~s}, 2 \mathrm{H}), 1.38(\mathrm{t}, J=7.1 \mathrm{~Hz}, 3 \mathrm{H}) .{ }^{13} \mathrm{C} \mathrm{NMR}(101 \mathrm{MHz}$, $\left.\mathrm{CDCl}_{3}\right) \delta 160.16,133.16,117.50,116.76,110.24,61.02,36.85$, 14.49. HRMS calcd for $\mathrm{C}_{8} \mathrm{H}_{9} \mathrm{O}_{2} \mathrm{~N}_{2} \mathrm{Cl}_{2}[\mathrm{M}-\mathrm{H}]^{-}$235.00466, found 235.00459 .

4.2.12. 5-(Aminomethyl)-3,4-dichloro-1H-pyrrole-2-carboxylic Acid (24). A mixture of the above ester 23 (1.42 g, $6.00 \mathrm{mmol})$, abs. EtOH $(60 \mathrm{~mL})$, and $10 \mathrm{M} \mathrm{NaOH}(10.8 \mathrm{~mL})$ was stirred at $90{ }^{\circ} \mathrm{C}$ under argon for $3 \mathrm{~h}$. The reaction mixture was concentrated under reduced pressure, dissolved in water $(20 \mathrm{~mL})$, filtered through cotton, and cooled to $0{ }^{\circ} \mathrm{C}$. Conc. $\mathrm{HCl}(\mathrm{aq})(7.5 \mathrm{~mL})$ was added, followed by $2 \mathrm{M} \mathrm{HCl}$ to adjust the $\mathrm{pH}$ to 8 . The precipitate was collected, washed with water, and air-dried to yield the title compound as a white amorphous powder (1.3 g, quant. yield). ${ }^{1} \mathrm{H}$ NMR (400 MHz, DMSO- $d_{6}$ ) $\delta 3.91(\mathrm{~s}, 2 \mathrm{H})$. HRMS calcd for $\mathrm{C}_{6} \mathrm{H}_{5} \mathrm{O}_{2} \mathrm{~N}_{2} \mathrm{Cl}_{2}[\mathrm{M}-\mathrm{H}]^{-}$ 206.97336, found 206.97342.

4.2.13. 5-(Phthalimidomethyl)-3,4-dichloro-1H-pyrrole-2carboxylic Acid (25). A homogeneous mixture of the above amino acid 24 (300 $\mathrm{mg}, 1.44 \mathrm{mmol}$ ) and powdered phthalic anhydride $(213 \mathrm{mg}, 1.44 \mathrm{mmol})$ in a $25 \mathrm{~mL}$ round-bottom flask was heated on an oil bath under a stream of argon from 150 to $180{ }^{\circ} \mathrm{C}$ for $15 \mathrm{~min}$ while stirring with a magnetic stirrer at $100 \mathrm{rpm}$ and agitating the flask manually. The temperature was kept at $180{ }^{\circ} \mathrm{C}$ for $30 \mathrm{~min}$ during which the reaction mixture caked. After cooling to r.t., the crude product was triturated successively with dichloromethane, EtOAc, and $1 \mathrm{M}$ $\mathrm{HCl}$, washed with water, and air-dried to get the title compound as a light gray amorphous solid $(270 \mathrm{mg}, 55 \%$ yield). ${ }^{1} \mathrm{H}$ NMR (400 MHz, DMSO- $\left.d_{6}\right) \delta 13.04(\mathrm{~s}, 1 \mathrm{H}), 12.57$ (s, 1H), 8.01-7.76 (m, 4H), $4.79(\mathrm{~s}, 2 \mathrm{H}) .{ }^{13} \mathrm{C}$ NMR (101 $\left.\mathrm{MHz}, \mathrm{DMSO}-d_{6}\right) \delta 167.31,160.04,134.42,131.83,127.18$, 123.14, 117.38, 114.98, 109.12, 33.00. HRMS calcd for $\mathrm{C}_{14} \mathrm{H}_{7} \mathrm{O}_{4} \mathrm{~N}_{2} \mathrm{Cl}_{2}[\mathrm{M}-\mathrm{H}]^{-} 336.97884$, found 336.97929 .

4.2.14. Methyl 4-(benzyloxy)-2-(3,4-dichloro-5-((1,3-dioxoisoindolin -2-yl)methyl)-1H-pyrrole-2-carboxamido)benzo[d]thiazole-6-carboxylate (26). A suspension of the above carboxylic acid $25(110 \mathrm{mg}, 0.324 \mathrm{mmol})$ in $\mathrm{SOCl}_{2}(1 \mathrm{~mL})$ was refluxed for $1 \mathrm{~h}$ and then concentrated under reduced pressure. To the solid residue were added methyl 2-amino-4(benzyloxy)benzo[d]thiazole-6-carboxylate (102 mg, 0.324 $\mathrm{mg}$ ) and normal grade toluene $(6.5 \mathrm{~mL})$, and the resulting suspension was refluxed overnight. After cooling to r.t., the 
precipitate was collected, washed with toluene, and air-dried to get the title compound as a gray amorphous solid $(165 \mathrm{mg}$, $81 \%$ yield). ${ }^{1} \mathrm{H}$ NMR (400 MHz, DMSO- $\left.d_{6}\right) \delta 12.44(\mathrm{~s}, 1 \mathrm{H})$, 12.39 (s, 1H), $8.30(\mathrm{~s}, 1 \mathrm{H}), 7.95-7.85(\mathrm{~m}, 4 \mathrm{H}), 7.61(\mathrm{~s}, 1 \mathrm{H})$, $7.55-7.50(\mathrm{~m}, 2 \mathrm{H}), 7.46-7.34(\mathrm{~m}, 3 \mathrm{H}), 5.30(\mathrm{~s}, 2 \mathrm{H}), 4.82(\mathrm{~s}$, $2 \mathrm{H}), 3.88(\mathrm{~s}, 3 \mathrm{H})$. HRMS calcd for $\mathrm{C}_{30} \mathrm{H}_{19} \mathrm{O}_{6} \mathrm{~N}_{4} \mathrm{Cl}_{2} \mathrm{~S}[\mathrm{M}-$ $\mathrm{H}]^{-}$633.04078, found 633.04098.

4.2.15. (5-((4-(Benzyloxy)-6-(methoxycarbonyl)benzo[d]thiazol-2-yl) carbamoyl)-3,4-dichloro-1H-pyrrol-2-yl)methanaminium 1,4-Dioxo-3,4-dihydro-1H-phthalazin-2ide (28). To a suspension of $26(100 \mathrm{mg}, 0.157 \mathrm{mmol})$ in abs. EtOH $(3.2 \mathrm{~mL})$ was added $80 \%$ aqueous hydrazine hydrate $\left(0.1 \mathrm{~mL}, 10\right.$ equiv). After stirring at $50{ }^{\circ} \mathrm{C}$ for $30 \mathrm{~min}$, full conversion to 27 was achieved; ${ }^{1} \mathrm{H}$ NMR $(400 \mathrm{MHz}$, DMSO- $\left.d_{6}\right) \delta 8.66(\mathrm{t}, J=5.6 \mathrm{~Hz}, 1 \mathrm{H}), 7.95(\mathrm{~d}, J=1.6 \mathrm{~Hz}, 1 \mathrm{H})$, 7.56-7.52 (m, 2H), 7.51-7.45 (m, 4H), 7.45-7.39 (m, 3H), $7.37-7.31(\mathrm{~m}, 1 \mathrm{H}), 5.29$ (s, 2H), 4.43 (d, $J=5.6 \mathrm{~Hz}, 2 \mathrm{H})$, $3.83(\mathrm{~s}, 3 \mathrm{H})$. The reaction mixture was concentrated under reduced pressure, suspended in $\mathrm{MeOH}(5 \mathrm{~mL})$, treated with $37 \% \mathrm{HCl}(\mathrm{aq})$ (three drops), and concentrated to get a white residue. ${ }^{1} \mathrm{H}$ NMR (400 MHz, DMSO- $d_{6}$ ) $\delta$ 12.50-12.36 (m, $2 \mathrm{H}), 11.41(\mathrm{~s}, 1 \mathrm{H}), 10.63(\mathrm{~s}, 2 \mathrm{H}), 9.10(\mathrm{t}, J=5.4 \mathrm{~Hz}, 1 \mathrm{H})$, $8.30(\mathrm{~d}, J=1.4 \mathrm{~Hz}, 1 \mathrm{H}), 7.76-7.71(\mathrm{~m}, 1 \mathrm{H}), 7.67-7.58(\mathrm{~m}$, $3 \mathrm{H}), 7.57-7.48(\mathrm{~m}, 3 \mathrm{H}), 7.47-7.41(\mathrm{~m}, 2 \mathrm{H}), 7.40-7.35(\mathrm{~m}$, $1 \mathrm{H}), 5.33(\mathrm{~s}, 2 \mathrm{H}), 4.46(\mathrm{~d}, J=5.3 \mathrm{~Hz}, 2 \mathrm{H}), 3.89$ (s, 3H). This reprotonated compound was suspended in 96\% EtOH and stirred at $80{ }^{\circ} \mathrm{C}$ overnight, and then the reaction mixture was concentrated and triturated with acetone to get the title compound 28 as a gray amorphous solid (90 mg, $88 \%$ yield). ${ }^{1} \mathrm{H}$ NMR (400 MHz, DMSO-d $\left.d_{6}\right) \delta 12.66(\mathrm{~s}, 1 \mathrm{H}), 12.51$ (s, $1 \mathrm{H}), 11.64(\mathrm{~s}, 1 \mathrm{H}), 8.42-8.28(\mathrm{~m}, 4 \mathrm{H}), 8.19-7.98(\mathrm{~m}, 2 \mathrm{H})$, 7.89 (dd, $J=5.9,3.3 \mathrm{~Hz}, 2 \mathrm{H}), 7.64$ (d, $J=1.5 \mathrm{~Hz}, 1 \mathrm{H}), 7.58-$ 7.49 (m, 2H), 7.48-7.41 (m, 2H), 7.41-7.35 (m, 1H), 5.34 (s, 2H), 4.06 (q, $J=5.2 \mathrm{~Hz}, 2 \mathrm{H}), 3.89$ (s, 3H). HRMS calcd for $\mathrm{C}_{22} \mathrm{H}_{19} \mathrm{O}_{4} \mathrm{~N}_{4} \mathrm{Cl}_{2} \mathrm{~S}[\mathrm{M}]^{+}$505.04986, found 505.04879; calcd for $\mathrm{C}_{8} \mathrm{H}_{5} \mathrm{O}_{2} \mathrm{~N}_{2}$ 161.03565 [M] $]^{-}$, found 161.03471 .

4.2.16. (5-((4-(Benzyloxy)-6-carboxybenzo[d]thiazol-2-yl)carbamo-yl)-3,4-dichloro-1H-pyrrol-2-yl)methanaminium 2-Carboxybenzoate (29). A mixture of the above ester 28 (50 $\mathrm{mg}, 0.075 \mathrm{mmol})$, abs. EtOH $(1.0 \mathrm{~mL})$, and $4 \mathrm{M} \mathrm{KOH}(0.15$ $\mathrm{mL}$ ) was stirred at $80{ }^{\circ} \mathrm{C}$ for $2 \mathrm{~h}$ and then at $50{ }^{\circ} \mathrm{C}$ overnight. The reaction mixture was concentrated, water $(1 \mathrm{~mL})$ was added, and the solids were filtered off. The filtrate was brought to $\mathrm{pH}=6$ by adding $1 \mathrm{M} \mathrm{HCl}$ and cooled to $0{ }^{\circ} \mathrm{C}$. The amorphous precipitate was collected, washed with water, and air-dried. ${ }^{1} \mathrm{H}$ NMR (400 MHz, DMSO- $\left.d_{6}\right) \delta 8.18(\mathrm{~s}, 1 \mathrm{H}), 8.08$ (s, 2H), 7.96-7.82 (m, 3H), 7.60-7.50 (m, 3H), 7.48-7.31 $(\mathrm{m}, 3 \mathrm{H}), 5.30(\mathrm{~s}, 2 \mathrm{H}), 3.94(\mathrm{~s}, 2 \mathrm{H})$, exchangeable protons were not observed.

4.2.17. (5-((4-(Benzyloxy)-6-carboxybenzo[d]thiazol-2-yl)carbamo-yl)-3,4-dichloro-1H-pyrrol-2-yl)methanaminium Chloride $(5 \cdot H C l)$. The above phthalate salt 29 was triturated with a fresh solution of $\mathrm{HCl}$ in $\mathrm{MeOH}(2 \times 1 \mathrm{~mL})$ (prepared by adding two drops of $37 \% \mathrm{HCl}(\mathrm{aq})$ to absolute methanol ( 5 $\mathrm{mL}$ ) (methanol was chosen as a solvent because of the known good solubility of phthalic acid in methanol)) to get the title compound as a brown amorphous powder (22 mg, 55\% yield). ${ }^{1} \mathrm{H}$ NMR (400 MHz, DMSO- $d_{6}$ ) $\delta 13.05$ (s, 1H), 12.64 (s, $1 \mathrm{H}), 12.47(\mathrm{~s}, 1 \mathrm{H}), 8.39-8.20(\mathrm{~m}, 4 \mathrm{H}), 7.64(\mathrm{~d}, J=1.3 \mathrm{~Hz}$, $1 \mathrm{H}), 7.55$ (d, $J=7.2 \mathrm{~Hz}, 2 \mathrm{H}), 7.47-7.42(\mathrm{~m}, 2 \mathrm{H}), 7.41-7.36$ $(\mathrm{m}, 1 \mathrm{H}), 5.33(\mathrm{~s}, 2 \mathrm{H}), 4.07(\mathrm{q}, J=5 \mathrm{~Hz}, 2 \mathrm{H}) .{ }^{13} \mathrm{C}$ NMR (101 $\left.\mathrm{MHz}, \mathrm{DMSO}-d_{6}\right)$ representative peaks: $\delta$ 167.46, 137.04, $128.91,128.76,128.58,127.47,125.72$, 116.82, 115.03, 112.68,
109.63, 70.58, 33.42. HRMS calcd for $\mathrm{C}_{21} \mathrm{H}_{17} \mathrm{O}_{4} \mathrm{~N}_{4} \mathrm{Cl}_{2} \mathrm{~S}[\mathrm{M}-$ $\mathrm{Cl}]^{+}$491.0348, found 491.0334.

4.2.18. Methyl 2-(3-fluoro-5-methyl-1H-pyrrole-2-carboxamido)-4-(1-phenylethoxy)benzo[d]thiazole-6-carboxylate (30). A suspension of $19(56 \mathrm{mg}, 0.35 \mathrm{mmol})$ and methyl 2amino-4-(1-phenylethoxy)benzo[d] thiazole-6-carboxylate $(114 \mathrm{mg}, 0.349 \mathrm{mmol})$ in toluene $(7 \mathrm{~mL})$ was refluxed overnight, equipped with a $\mathrm{CaCl}_{2}$ tube. After cooling to r.t., the precipitate was collected and washed with toluene to get the title compound as a light gray amorphous powder (91 mg, 57\% yield). ${ }^{1} \mathrm{H}$ NMR (400 MHz, DMSO- $\left.d_{6}\right) \delta 12.23$ (s, $\left.1 \mathrm{H}\right), 11.37$ (s, $1 \mathrm{H}), 8.17$ (d, $J=1.5 \mathrm{~Hz}, 1 \mathrm{H}), 7.49-7.42(\mathrm{~m}, 2 \mathrm{H}), 7.40-$ $7.31(\mathrm{~m}, 3 \mathrm{H}), 7.29-7.25(\mathrm{~m}, 1 \mathrm{H}), 6.91$ (app t, $J=4.2 \mathrm{~Hz}$, $1 \mathrm{H}), 5.80(\mathrm{q}, J=6.1 \mathrm{~Hz}, 1 \mathrm{H}), 3.80(\mathrm{~s}, 3 \mathrm{H}), 1.99(\mathrm{~s}, 3 \mathrm{H}), 1.64$ $(\mathrm{d}, J=6.3 \mathrm{~Hz}, 3 \mathrm{H}) .{ }^{19} \mathrm{~F}$ NMR $\left(376 \mathrm{MHz}, \mathrm{DMSO}-d_{6}\right) \delta$ $-153.97(\mathrm{~d}, J=4 \mathrm{~Hz})$. HRMS calcd for $\mathrm{C}_{23} \mathrm{H}_{19} \mathrm{O}_{4} \mathrm{~N}_{3} \mathrm{FS}$ 452.10858; found 452.10924 [M - H] $]^{-}$.

4.2.19. 2-(3-Fluoro-5-methyl-1H-pyrrole-2-carboxamido)4-(1-phenylethoxy)benzo[d]thiazole-6-carboxylic Acid (31). A solution of the above ester $30(70 \mathrm{mg}, 0.154 \mathrm{mmol})$ in $\mathrm{MeOH}(3.0 \mathrm{~mL})$ and $2 \mathrm{M} \mathrm{NaOH}(0.40 \mathrm{~mL})$ was stirred at 40 ${ }^{\circ} \mathrm{C}$ overnight. $\mathrm{NaOH}(2 \mathrm{M}, 0.40 \mathrm{~mL})$ was added and stirred another night, and then the reaction mixture was concentrated. The residue was suspended in water $(2 \mathrm{~mL})$, the $\mathrm{pH}$ was adjusted to 2 by adding $4 \mathrm{M} \mathrm{HCl}$, and the precipitate was collected, washed with water, air-dried, and triturated with $\mathrm{MeOH}$ to get the title compound as a beige amorphous solid (55 mg, 81\% yield). ${ }^{1} \mathrm{H}$ NMR (400 MHz, DMSO-d $\left.d_{6}\right) \delta 12.82$ (s, 1H), $12.20(\mathrm{~s}, 1 \mathrm{H}), 11.37(\mathrm{~s}, 1 \mathrm{H}), 8.13(\mathrm{~s}, 1 \mathrm{H}), 7.52-7.40$ $(\mathrm{m}, 2 \mathrm{H}), 7.40-7.31(\mathrm{~m}, 3 \mathrm{H}), 7.31-7.20(\mathrm{~m}, 1 \mathrm{H}), 6.91$ (app t, $J=4.2 \mathrm{~Hz}, 1 \mathrm{H}), 5.79(\mathrm{q}, J=6.3 \mathrm{~Hz}, 1 \mathrm{H}), 1.99(\mathrm{~s}, 3 \mathrm{H}), 1.64$ (d, $J=6.3 \mathrm{~Hz}, 3 \mathrm{H}) .{ }^{19} \mathrm{~F}$ NMR $\left(376 \mathrm{MHz}, \mathrm{DMSO}-d_{6}\right) \delta-154.06$ $(\mathrm{d}, J=4 \mathrm{~Hz}) .{ }^{13} \mathrm{C}$ NMR $\left(101 \mathrm{MHz}, \mathrm{DMSO}-d_{6}\right) \delta 166.92$, $159.75,156.78,154.36,151.82,148.98,142.57,132.83,128.61$, 127.55, 126.31, 125.53, $120.98(\mathrm{~d}, J=5.4 \mathrm{~Hz}), 115.90,110.44$, $107.83(\mathrm{~d}, J=15.0 \mathrm{~Hz}), 106.18$ (d, $J=13.7 \mathrm{~Hz}$ ), 75.48, 24.33, 7.17. HRMS calcd for $\mathrm{C}_{22} \mathrm{H}_{17} \mathrm{O}_{4} \mathrm{~N}_{3} \mathrm{FS}$ 438.09293; found 438.09338 $[\mathrm{M}-\mathrm{H}]^{-}$.

4.2.20. tert-Butyl 2-(4-fluoro-5-methyl-1H-pyrrole-2-carboxamido)-4-isopropoxybenzo[d]thiazole-6-carboxylate (32). A suspension of 13 (58 $\mathrm{mg}, 0.36 \mathrm{mmol}$ ) and methyl 2amino-4-(2-propyloxy)benzo[d] thiazole-6-carboxylate $(93 \mathrm{mg}$, $0.30 \mathrm{mmol})$ in toluene $(7 \mathrm{~mL})$ was stirred at $130{ }^{\circ} \mathrm{C}$ overnight. The gray amorphous precipitate was collected and washed with toluene. Yield: $79 \%$ (104 mg). ${ }^{1} \mathrm{H}$ NMR (400 MHz, DMSO$\left.d_{6}\right) \delta 12.66(\mathrm{~s}, 1 \mathrm{H}), 11.85(\mathrm{~s}, 1 \mathrm{H}), 8.13(\mathrm{~d}, J=1 \mathrm{~Hz}, 1 \mathrm{H}), 7.44$ $(\mathrm{d}, J=1 \mathrm{~Hz}, 1 \mathrm{H}), 7.26(\mathrm{~d}, J=2.3 \mathrm{~Hz}, 1 \mathrm{H}), 4.95-4.84(\mathrm{~m}$, $1 \mathrm{H}), 2.20(\mathrm{~s}, 3 \mathrm{H}), 1.36(\mathrm{~d}, J=6.0 \mathrm{~Hz}, 6 \mathrm{H}) . \mathrm{MS} 432.2[\mathrm{M}-$ $\mathrm{H}]^{-}$.

4.2.21. 2-(4-Fluoro-5-methyl-1H-pyrrole-2-carboxamido)4-isopropoxybenzo[d]thiazole-6-carboxylic Acid (33). The above tert-butyl ester $32(75 \mathrm{mg}, 0.173 \mathrm{mmol})$ was suspended in dichloromethane $(3 \mathrm{~mL})$. Trifluoroacetic acid $(0.13 \mathrm{~mL}$, $1.73 \mathrm{mmol}$ ) was added and the suspension turned into a brown solution. The reaction mixture was stirred overnight at room temperature. The solvent was removed under reduced pressure and the residue was triturated with methanol to give 33 as an amorphous solid. Yield: 98\% (64 mg). ${ }^{1} \mathrm{H}$ NMR (400 MHz, DMSO- $\left.d_{6}\right) \delta 12.92(\mathrm{~s}, 1 \mathrm{H}), 12.65(\mathrm{~s}, 1 \mathrm{H}), 11.84(\mathrm{~s}, 1 \mathrm{H}), 8.17$ $(\mathrm{d}, J=1.2 \mathrm{~Hz}, 1 \mathrm{H}), 7.48(\mathrm{~s}, 1 \mathrm{H}), 7.26(\mathrm{~d}, J=2.7 \mathrm{~Hz}, 1 \mathrm{H})$, 4.89 (hept, $J=6 \mathrm{~Hz}, 1 \mathrm{H}), 2.19$ (s, 3H), 1.36 (d, $J=6 \mathrm{~Hz}, 6 \mathrm{H})$. HRMS calcd for $\mathrm{C}_{17} \mathrm{H}_{17} \mathrm{O}_{4} \mathrm{~N}_{3} \mathrm{FS}[\mathrm{M}+\mathrm{H}]^{+} 378.09183$, found 378.09203 . 
4.3. Biological Assays. 4.3.1. Determination of Inhibitory Activity on E. coli. DNA Gyrase. The supercoiling assay for the determination of $\mathrm{IC}_{50}$ values was performed according to previously reported procedures. ${ }^{30}$

\section{ASSOCIATED CONTENT}

\section{(5) Supporting Information}

The Supporting Information is available free of charge at https://pubs.acs.org/doi/10.1021/acsomega.1c00331.

Additional experimental data; copies of ${ }^{1} \mathrm{H}$ and ${ }^{13} \mathrm{C}$ and 2D NMR spectra; and single-crystal X-ray diffraction analysis (PDF)

Compound 10 (CIF)

Compound 11 (CIF)

checkCIF/PLATON report (PDF)

\section{Accession Codes}

CCDC 2022198 and 2022199 contain the supplementary crystallographic data for this paper. These data can be obtained free of charge via www.ccdc.cam.ac.uk/data_request/cif, or by emailing data_request@ccdc.cam.ac.uk, or by contacting The Cambridge Crystallographic Data Centre, 12 Union Road, Cambridge CB21EZ, UK; fax: +44 1223336033.

\section{AUTHOR INFORMATION}

\section{Corresponding Author}

Danijel Kikelj - Faculty of Pharmacy, University of Ljubljana, 1000 Ljubljana, Slovenia; Email: danijel.kikelj@ffa.uni-lj.si

\section{Authors}

Andrej Emanuel Cotman - Faculty of Pharmacy, University of Ljubljana, 1000 Ljubljana, Slovenia; (1) orcid.org/00000003-2528-396X

Thomas Guérin - Université de Strasbourg, CNRS, UMR 7042-LIMA, Strasbourg 67087, France

Ivana Kovačevic - Faculty of Sciences, Department of Chemistry, Biochemistry and Environmental Protection, University of Novi Sad, 21000 Novi Sad, Serbia

Davide Benedetto Tiz - Faculty of Pharmacy, University of Ljubljana, 1000 Ljubljana, Slovenia

Martina Durcik - Faculty of Pharmacy, University of Ljubljana, 1000 Ljubljana, Slovenia; orcid.org/00000002-9218-1771

Federica Fulgheri - Faculty of Pharmacy, University of Ljubljana, 1000 Ljubljana, Slovenia

Stefan Možina - Faculty of Pharmacy, University of Ljubljana, 1000 Ljubljana, Slovenia; 이이이.org/00000002-7416-6981

Daniela Secci - Faculty of Pharmacy, University of Ljubljana, 1000 Ljubljana, Slovenia; (1) orcid.org/0000-0002-16281850

Maša Sterle - Faculty of Pharmacy, University of Ljubljana, 1000 Ljubljana, Slovenia; (1) orcid.org/0000-0003-38985194

Janez Ilaš - Faculty of Pharmacy, University of Ljubljana, 1000 Ljubljana, Slovenia; orcid.org/0000-0002-01240474

Anamarija Zega - Faculty of Pharmacy, University of

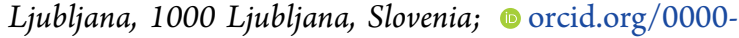
0003-4065-0019

Nace Zidar - Faculty of Pharmacy, University of Ljubljana, 1000 Ljubljana, Slovenia; (1) orcid.org/0000-0003-19050158
Lucija Peterlin Mašič - Faculty of Pharmacy, University of Ljubljana, 1000 Ljubljana, Slovenia

Tihomir Tomašic - Faculty of Pharmacy, University of Ljubljana, 1000 Ljubljana, Slovenia; (ㅇ orcid.org/00000001-5534-209X

Frédéric R. Leroux - Université de Strasbourg, CNRS, UMR 7042-LIMA, Strasbourg 67087, France; 다이. orcid.org/00000001-8900-5753

Gilles Hanquet - Université de Strasbourg, CNRS, UMR 7042-LIMA, Strasbourg 67087, France

Complete contact information is available at:

https://pubs.acs.org/10.1021/acsomega.1c00331

\section{Notes}

The authors declare no competing financial interest.

\section{ACKNOWLEDGMENTS}

Some of the research leading to these results was conducted as part of the ND4BB ENABLE Consortium and has received support from the Innovative Medicines Initiative Joint Undertaking under Grant No. 115583, resources of which comprise financial contributions from the European Union's seventh framework program (FP7/2007-2013) and EFPIA companies' in-kind contribution. We gratefully acknowledge the Slovenian Research Agency (Grant No. P1-0208), COST Action CA15135 MuTaLig, the French Agence Nationale pour la Recherche (ANR) (grant number ANR-17-CE07-0008-01, DEFIS), CNRS, and Universite' de Strasbourg for financial support. The French Fluorine Network (GIS Fluor) is also acknowledged. T.G. is much grateful to the French Ministry of Education and Research for funding. The authors thank L. Karmazin and C. Bailly from the Service de radiocristallographie de la Fédération de Chimie Le Bel FR 2010 for the SCXRD analyses. Maja Frelih is acknowledged for the acquisition of HRMS spectra and Dr. Žiga Skok for performing the enzyme inhibition assay.

\section{REFERENCES}

(1) Kovalerchik, D.; Singh, R. P.; Schlesinger, P.; Mahajni, A.; Shefer, S.; Fridman, M.; Ilan, M.; Carmeli, S. Bromopyrrole Alkaloids of the Sponge Agelas oroides Collected Near the Israeli Mediterranean Coastline. J. Nat. Prod. 2020, 83, 374-384.

(2) de Souza, R. T. M. P.; Freire, V. F.; Gubiani, J. R.; Ferreira, R. O.; Trivella, D. B. B.; Moraes, F. C.; Paradas, W. C.; Salgado, L. T.; Pereira, R. C.; Amado Filho, G. M.; Ferreira, A. G.; Williams, D. E.; Andersen, R. J.; Molinski, T. F.; Berlinck, R. G. S. Bromopyrrole Alkaloid Inhibitors of the Proteasome Isolated from a Dictyonella Sp. Marine Sponge Collected at the Amazon River Mouth. J. Nat. Prod. 2018, 81, 2296-2300.

(3) Ma, Z.; Wang, X.; Wang, X.; Rodriguez, R. A.; Moore, C. E.; Gao, S.; Tan, X.; Ma, Y.; Rheingold, A. L.; Baran, P. S.; Chen, C. Asymmetric Syntheses of Sceptrin and Massadine and Evidence for Biosynthetic Enantiodivergence. Science 2014, 346, 219-224.

(4) Cotman, A. E. Escaping from Flatland: Stereoconvergent Synthesis of 3-Dimensional Scaffolds via Ruthenium(II)-Catalyzed Noyori-Ikariya Transfer Hydrogenation. Chem. - Eur. J. 2021, 27, 3953.

(5) Singh, S. B. Discovery and Development of Kibdelomycin, a New Class of Broad-Spectrum Antibiotics Targeting the Clinically Proven Bacterial Type II Topoisomerase. Bioorg. Med. Chem. 2016, 24, 6291-6297.

(6) Sawa, R.; Takahashi, Y.; Hashizume, H.; Sasaki, K.; Ishizaki, Y.; Umekita, M.; Hatano, M.; Abe, H.; Watanabe, T.; Kinoshita, N.; Homma, Y.; Hayashi, C.; Inoue, K.; Ohba, S.; Masuda, T.; Arakawa, M.; Kobayashi, Y.; Hamada, M.; Igarashi, M.; Adachi, H.; Nishimura, 
Y.; Akamatsu, Y. Amycolamicin: A Novel Broad-Spectrum Antibiotic Inhibiting Bacterial Topoisomerase. Chem.-Eur. J. 2012, 18, 1577215781.

(7) Basarab, G. S.; Hill, P. J.; Garner, C. E.; Hull, K.; Green, O.; Sherer, B. A.; Dangel, P. B.; Manchester, J. I.; Bist, S.; Hauck, S.; Zhou, F.; Uria-Nickelsen, M.; Illingworth, R.; Alm, R.; Rooney, M.; Eakin, A. E. Optimization of Pyrrolamide Topoisomerase II Inhibitors Toward Identification of an Antibacterial Clinical Candidate (AZD5099). J. Med. Chem. 2014, 57, 6060-6082.

(8) Vandyck, K.; HACHÉ, G. Y. P.; Last, S. J.; Gowan, D. C. M.; Rombouts, G.; Verschueren, W. G.; Raboisson, P. J.-M. B. Sulphamoylpyrrolamide Derivatives and the Use Thereof as Medicaments for the Treatment of Hepatitis b. WO2014184350A1November 20,2014 .

(9) Gjorgjieva, M.; Tomašič, T.; Kikelj, D.; Mašič, L. P. Benzothiazole-Based Compounds in Antibacterial Drug Discovery. Curr. Med. Chem. 2019, 25, 5218-5236.

(10) Zidar, N.; Macut, H.; Tomašič, T.; Mašič, L. P.; Ilaš, J.; Zega, A.; Tammela, P.; Kikelj, D. New N -Phenyl-4,5-Dibromopyrrolamides as DNA Gyrase B Inhibitors. MedChem Comm 2019, 10, 1007-1017.

(11) Tiz, D. B.; Skok, Ž.; Durcik, M.; Tomašič, T.; Mašič, L. P.; Ilaš, J.; Zega, A.; Draskovits, G.; Révész, T.; Nyerges, Á.; Pál, C.; Cruz, C. D.; Tammela, P.; Žigon, D.; Kikelj, D.; Zidar, N. An Optimised Series of Substituted N-Phenylpyrrolamides as DNA Gyrase B Inhibitors. Eur. J. Med. Chem. 2019, 167, 269-290.

(12) Lamut, A.; Cruz, C. D.; Skok, Ž.; Barančoková, M.; Zidar, N.; Zega, A.; Mašič, L. P.; Ilaš, J.; Tammela, P.; Kikelj, D.; Tomašič, T. Design, Synthesis and Biological Evaluation of Novel DNA Gyrase Inhibitors and Their Siderophore Mimic Conjugates. Bioorg. Chem. 2020, 95, No. 103550.

(13) Lamut, A.; Skok, Ž.; Barančoková, M.; Gutierrez, L. J.; Cruz, C. D.; Tammela, P.; Draskovits, G.; Szili, P. É.; Nyerges, Á; Pál, C.; Molek, P.; Bratkovič, T.; Ilaš, J.; Zidar, N.; Zega, A.; Enriz, R. D.; Kikelj, D.; Tomašič, T. Second-Generation 4,5,6,7-Tetrahydrobenzo[d]Thiazoles as Novel DNA Gyrase Inhibitors. Future Med. Chem. 2020, 12, 277-297.

(14) Jakopin, Ž.; Ilaš, J.; Barančoková, M.; Brvar, M.; Tammela, P.; Sollner Dolenc, M.; Tomašič, T.; Kikelj, D. Discovery of Substituted Oxadiazoles as a Novel Scaffold for DNA Gyrase Inhibitors. Eur. J. Med. Chem. 2017, 130, 171-184.

(15) Cotman, A. E.; Trampuž, M.; Brvar, M.; Kikelj, D.; Ilaš, J.; Peterlin-Mašič, L.; Montalvão, S.; Tammela, P.; Frlan, R. Design, Synthesis, and Evaluation of Novel Tyrosine-Based DNA Gyrase B Inhibitors. Arch. Pharm. 2017, 350, No. 1700087.

(16) Nyerges, A.; Tomašič, T.; Durcik, M.; Revesz, T.; Szili, P.; Draskovits, G.; Bogar, F.; Skok, Ž.; Zidar, N.; Ilaš, J.; Zega, A.; Kikelj, D.; Daruka, L.; Kintses, B.; Vasarhelyi, B.; Foldesi, I.; Kata, D.; Welin, M.; Kimbung, R.; Focht, D.; Mašič, L. P.; Pal, C. Rational Design of Balanced Dual-Targeting Antibiotics with Limited Resistance. PLoS Biol. 2020, 18, No. e3000819.

(17) Sherer, B. A.; Hull, K.; Green, O.; Basarab, G.; Hauck, S.; Hill, P.; Loch, J. T.; Mullen, G.; Bist, S.; Bryant, J.; Boriack-Sjodin, A.; Read, J.; DeGrace, N.; Uria-Nickelsen, M.; Illingworth, R. N.; Eakin, A. E. Pyrrolamide DNA Gyrase Inhibitors: Optimization of Antibacterial Activity and Efficacy. Bioorg. Med. Chem. Lett. 2011, $21,7416-7420$.

(18) Basarab, G. S.; Hill, P.; Sherer, B.; Zhou, F. 2- (Piperidin-1-Yl) -4-Heterocyclyl-Thiazole-5-Carboxylic Acid Derivatives against Bacterial Infections. WO2010067123A1June 17, 2010.

(19) Worrell, B. T.; Hein, J. E.; Fokin, V. V. Halogen Exchange (Halex) Reaction of 5-Iodo-1,2,3-Triazoles: Synthesis and Applications of 5-Fluorotriazoles. Angew. Chem., Int. Ed. 2012, 51, 1179111794.

(20) Heeran, D.; Sandford, G. Fluorination of Pyrrole Derivatives by Selectfluor. Tetrahedron 2016, 72, 2456-2463.

(21) Zhang, Y.; Shibatomi, K.; Yamamoto, H. Lewis Acid Catalyzed Highly Selective Halogenation of Aromatic Compounds. Synlett 2005, 2005, 2837-2842.
(22) René, A.; Quilan, M.; Deng, Y.; Cheng, Y.; Teleha, C. A.; Raboisson, P.; Bonfanti, J.-F.; Fortin, J.; Charette, André. B.; Pannecoucke, X.; Poisson, T.; Jubault, P. Practical Synthesis of Ethyl 3-Fluoro-1-Pyrrole-2-Carboxylate: A Key Fragment of a Potent Drug Candidate against Hepatitis B Virus. Org. Process Res. Dev. 2020, 24, 792-801.

(23) Smith, K. M.; Minnetian, O. M. Novel Porphyrins from Copper(II)-Mediated Cyclizations of 1',8'-Dimethyl-A,C-Biladiene Salts: Mechanism of the Cyclization Reaction. J. Org. Chem. 1985, 50, 2073-2080.

(24) Carey, F. A.; Sundberg, R. J. Advanced Organic Chemistry: Part B: Reaction and Synthesis; 5th ed.; Springer: US, 2007.

(25) Yamamura, S.; Toda, M.; Hirata, Y. Modified Clemmensen Reduction: Cholestane. Org. Synth. 2003, 53, 86.

(26) Boardman, A.; Small, R. W. H.; Worrall, I. J. Structure of Catena-Dichloro- $\mu$-(1,4-Dioxane-O,O')-(1,4-Dioxane)Zinc(II), [Zn$\left(\mathrm{C}_{4} \mathrm{H}_{8} \mathrm{O}_{2}\right)_{2} \mathrm{Cl}_{2}$. Acta Crystallogr., Sect. C: Cryst. Struct. Commun. 1983, 39, 1005-1007.

(27) Brewster, J. H. Reductions at Metal Surfaces. II. A Mechanism for the Clemmensen Reduction. J. Am. Chem. Soc. 1954, 76, 63646368.

(28) Staudinger, H.; Meyer, J. Ü. New Organic Compounds of Phosphorus. III. Phosphine-Methylene Derivatives and Phosphinimines. Helv. Chim. Acta 1919, 2, 635-646.

(29) Durcik, M.; Toplak, Ž.; Zidar, N.; Ilaš, J.; Zega, A.; Kikelj, D.; Mašič, L. P.; Tomašič, T. Efficient Synthesis of Hydroxy-Substituted 2-Aminobenzo[d]Thiazole-6-Carboxylic Acid Derivatives as New Building Blocks in Drug Discovery. ACS Omega 2020, 5, 8305-8311. (30) Zidar, N.; Tomašič, T.; Macut, H.; Sirc, A.; Brvar, M.; Montalvão, S.; Tammela, P.; Ilaš, J.; Kikelj, D. New N-Phenyl-4,5Dibromopyrrolamides and N-Phenylindolamides as ATPase Inhibitors of DNA Gyrase. Eur. J. Med. Chem. 2016, 117, 197-211. 